\title{
Slavery and the Atlantic Slave Trade in Brazil and Cuba from an Afro-Atlantic Perspective
}

DOI

http://dx.doi.org/10.1590/2236-463320161201

\section{Ana Lucia Araújo \\ Howard University \\ Washington, DC, Estados Unidos \\ aaraujo@Howard.edu \\ RODRIGUES, Jaime. De costa a costa: escravos,} marinheiros e intermediários do tráfico negreiro de Angola ao Rio de Janeiro, 1780-1860. São Paulo: Companhia das Letras, 2005; HAWTHORNE, Walter. From Africa to Brazil: Culture, Identity, and an Atlantic Slave Trade, 1600-1830. New York: Cambridge University Press, 2010; SWEET, James H. Domingos Álvares, African Healing, and the Intellectual History of the Atlantic World. Chapel Hill: University of North Carolina Press, 2011; FERREIRA, Roquinaldo Amaral, Cross-Cultural Exchange in the Atlantic World: Angola and Brazil During the Era of the Slave Trade. New York: Cambridge University Press, 2012.

2

BERGAD, Laird W. The Comparative Histories of Slavery in Brazil, Cuba, and the United States. New York: Cambridge University Press, 2007; BERBEL, Márcia Regina, Rafael de Bivar Marquese, and Tâmis Parron. Escravidão e política: Brasil e Cuba, c. 1790-1850. São Paulo: Editora Hucitec, 2010; COWLING, Camillia. Conceiving Freedom: Women of Color, Gender, and the Abolition of Slavery in Havana and Rio De Janeiro. Chapel Hill: University of North Carolina Press, 2013; GRADEN, Dale Torston. Disease, Resistance, and Lies: The Demise of the Transatlantic Slave Trade to Brazil and Cuba. Baton Rouge: Louisiana State University Press, 2014 e PARRON, Tâmis Peixoto, A política da escravidão na era da liberdade: Estados Unidos, Brasil e Cuba, 1787-1846, Tese (Doutorado em História Social), Faculdade de Letras e Ciências Humanas, Universidade de São Paulo, São Paulo, 2015.

On Afro-Cuban cabildos see HOWARD, Philip A. Changing History: Afro-Cuban Cabildos and Societies of Color in the Nineteenth Century. Baton Rouge: Louisiana State Unviersity Press, 1998; CHILDS, Matt D. The 1812 Aponte Rebellion in Cuba and the Struggle against Atlantic Slavery. Chapel Hill: University of North Carolina Press, 2006.

SOARES, Mariza de Carvalho. People of faith: slavery and African Catholics in eighteenthcentury Rio de Janeiro. Durham, NC: Duke University Press, 2011.

\begin{abstract}
This text presents the seven articles that forms the dossier, stressing its common bases and some of its particularities.
\end{abstract}

\section{Resumo}

Este texto apresenta os sete artigos que compõe o dossiê homônimo, destacando suas bases comuns e algumas das particularidades de cada um.

\author{
Palavras-chave \\ Escravidão, Brasil, Cuba.
}

\section{Keywords}

Slavery, Brazil, Cuba.

A growing number of studies comparing slavery in the Americas were published over the last two decades. This recent scholarship has greatly stressed the importance of studying the role of Africa in the Atlantic slave trade, in order to understand its dynamics and to grasp the ways enslaved Africans contributed, economically, politically, and culturally, to the construction of the Americas. ${ }^{1}$ Although most comparative studies on slavery in the Americas have focused on Brazil and the United States, the two largest slave societies of the western hemisphere, new research has also explored the many similarities between Brazil and other slave societies, especially Cuba. ${ }^{2}$

This new wave of studies comparing Brazil and Cuba is well justified. Colonized by the Portuguese and the Spanish, both societies were marked by the presence of the Catholic Church. In Brazil and Cuba, as in other parts of the Spanish Americas, slaves were baptized and could marry. In urban centers such as Mexico, Lima, Montevideo, Rio de Janeiro, Havana, Matanzas, and Salvador, slaves joined Catholic lay brotherhoods (irmandades or cofradías). In Cuban urban areas, slaves also joined cabildos de nación. ${ }^{3}$ These associations, which provided burial services and served as mutual aid societies to its members, were organized along ethnic lines. They allowed slaves to endure the hardships of slavery and to prepare the transition to freedom. ${ }^{4}$

Brazil imported approximately 5,1 million enslaved Africans, whereas Cuban slave imports are estimated at 778,000 slaves. In the seventeenth century, Brazil was a great producer of sugar, whereas Cuban sugar industry gained importance after the rise of the Saint-Domingue slavery 
On sugar production in Brazil, see SCHWARTZ, Stuart B. 1985. Sugar plantations in the formation of Brazilian society: Bahia, 1550-1835. Cambridge: Cambridge University Press. On the growth of sugar production in Cuba during the nineteenth century see FERRER, Ada. Freedom's Mirror: Cuba and Haiti in the Age of Revolution. New York: Cambridge University Press, 2014. On coffee production in Cuba see VAN NORMAN, William C. Shade grown slavery the lives of slaves on coffee plantations in Cuba. Nashville, TN: Vanderbilt University Press, 2012; and in Brazil, see SALLES, Ricardo. E o vale era o escravo: Vassouras, século XIX: senhores e escravos no coração do Império. Rio de Janeiro: Civilização Brasileira, 2008.

6

On Yoruba religions in the diaspora, see OLUPONA, Jacob K., and Terry Rey, Órisà Devotion as World Religion: The Globalization of Yorùbá Religious Culture. Madison, WI: University of Wisconsin Press, 2008.

7

On warfare in the Bight of Benin and in Bahia and Cuba see BARCIA, Manuel. West African warfare in Bahia and Cuba: soldier slaves in the Atlantic world, 1807-1844. 0xford: 0xford University Press, 2014, and REIS, João José, Rebelião escrava no Brasil: a história do levante dos malês em 1835. São Paulo: Companhia das Letras, 2003.

8

On Cuba this point is emphasized by ZEUSKE, Michael. Amistad: A Hidden Network of Slavers and Merchants. Princeton: Markus Wiener Publishers, 2015. On Brazil, see CHALHOUB, Sidney. A força da escravidão: ilegalidade e costume no Brasil oitocentista. São Paulo: Companhia das Letras, 2012.

9

On the slave trade to Cuba, see BERGAD, Laird W., Fe Iglesias García, and Maria del Carmen Barcia. The Cuban Slave Market, 1790-1880. New York: Cambridge University Press, 1995.

10

For estimates, see the Transatlantic Slave Trade Database: Voyages, www.slavevoyages.org.

11

See SCHIMIDT-NOWARA, Christopher. Empire and Antislavery: Spain, Cuba, and Puerto Rico, 1833-1874. Pittsburgh: Pittsburgh University Press 1999, chapter 7 and SCHIMIDT-NOWARA, Christopher. Slavery, Freedom, and Abolition in Latin America and the Atlantic World. Albuquerque: University of New Mexico Press, 2011, p. 90-91.

12

On the limitations of this law see SCOT, Rebecca. Slave Emancipation in Cuba: The Transition to Free Labor, 1860-1899. Pittsburgh, PA: University of Pittsburgh Press, 2000, p. 128.

13

On the limitations of this law see SCOT, Rebecca. Slave Emancipation in Cuba: The Transition to Free Labor, 1860-1899. Pittsburgh, PA: University of Pittsburgh Press, 2000, p. 128. rebellion. In the early nineteenth century, both Brazil and Cuba became great producers of coffee. ${ }^{5}$ There were also other similarities. Most enslaved Africans transported to Brazil and Cuba came from West African and West Central African areas where Bantu and Yoruba languages predominated. From Africa, they brought similar spiritual traditions that combined with Catholicism made possible the emergence of religions such as Candomblé and Santeria. ${ }^{6}$ Likewise, they also carried with them warfare knowledge, which they employed to organize slave revolts, during the eighteenth and the nineteenth centuries. ${ }^{7}$ The legal systems of Latin American colonial societies, including Brazil and Cuba, largely relied on Roman Law, dimension that impacted enslaved populations in similar ways. In the two societies, slaves were able to obtain manumission and were allowed to purchase their liberty. Slaves went to court to petition their masters in order to obtain their freedom and also to denounce bad treatment and sexual abuse. Moreover, despite their different sizes, both in Brazil and Cuba, like in Mexico, Peru, and Argentina, slavery was present not only in plantation zones, but also in urban areas.

In Brazil and Cuba, the slave trade engendered great profits to slave merchants, who continued to import slaves after its legal abolition. ${ }^{8}$ Between 1820, when the slave trade to Cuba was prohibited for the first time, and 1867, when its ban was effectively enforced, approximately 499,580 enslaved Africans disembarked in the Spanish colony. ${ }^{9}$ Likewise, after its first legal prohibition in 1831, Brazil imported approximately 480,000 slaves. $^{10}$ In both societies slave owners and planters obtained important gains. Slavery was a profitable institution that greatly contributed to the development of capitalism in Europe and the Americas during the nineteenth century. Because slavery was a lucrative institution, Brazilian ad Cuban slave owners and planters greatly resisted the end of slavery. ${ }^{11}$ Such opposition led to the adoption of gradual emancipation, which except for the Dominican Republic, was also the chosen approach by the local elites in all other Latin American societies.

As Cuba was divided by a war for independence, on July 4, 1870, the Spanish Parliament passed the Moret Law emancipating all children born to slave mothers after its enactment. ${ }^{12}$ Additionally, the same law freed the slaves older than sixty years old. Yet, the law established a number of restrictions, including that freed newborns should remain under the custody of the mother's master. On September 28, 1871, Brazil passed a similar legislation. The Rio Branco Law (or Free Womb Law) freed the children of enslaved mothers who were born after its passing. Similar to the Moret Law, the scope of the Rio Branco Law was also limited and in practice did not free any living slaves in Brazil.

Cuba passed the Patronato Law in 1880 which determined the end of slavery and replaced it with an eight-year period of apprenticeship. Therefore, freed slaves were renamed patrocinados, whereas the former masters were named patronos. ${ }^{13}$ In 1885, Brazil enacted the Law SaraivaCotegipe or Sexagenarian Law, which emancipated all slaves older than sixty years old. Eventually the Cuban patronato system ended on October 7 , 1886, prior to the initially established date, by definitely abolishing slavery.

Brazilian slavery was abolished only on May 13, 1888. In both Brazil and Cuba, the transition from slavery to freedom presented several elements in common. Whereas in Brazil the slave workforce was mainly replaced with workers of European origin, Cuba encouraged the 
immigration of Asian indentured workers. Moreover, in both countries the post-abolition period was marked by the maintenance of racial relations in which the idea of mestizaje and racial democracy predominated. Like in other post-slave societies in the Americas, in Brazil and Cuba, the newly freed populations and their descendants faced a long history of racism and of social and economic exclusion.

By exploring the history of slavery and the Atlantic slave trade in the South Atlantic world, during the eighteenth and the nineteenth centuries, this special number looks at the example of Cuba as a counterpoint for the study of slavery in Brazil. Also, the various articles explore the history of these two slave societies by giving Africa a central role in the study of the Atlantic slave trade. To this end, four articles of this number explore the mechanisms of the slave trade to Brazil and Cuba, whereas the three other articles rather examine the engines of slavery in these two slave societies of the Americas, with a particular attention to the role of enslaved and freed women.

In his paper, Carlos da Silva Jr. examines the long history of exchanges between Bahia and the Bight of Benin during the eighteenth century, in order to understand the dynamics of the Atlantic slave trade in the ports of this region. Da Silva explains why slave merchants from Bahia preferred to purchase captives of particular linguistic groups, such as the Ardra, the Mina, and the Jeje, in detriment of others. He also emphasizes how the inter-state wars in the Bight of Benin and its hinterland as well as the interactions among the various social actors involved in the slave trade contributed to this choice. Exploring new archival sources and diving deeply on the history of West Africa to examine slavery in Bahia, da Silva's article contributes to a long-standing tradition of studies that examined this region over the last six decades.

Exploring the early nineteenth-century slave trade to Cuba, Michael Zeuske looks at the intertwined trajectories of an African-born enslaved man and a European slave merchant. Roberto (or Robin or Robert) Botefeur was born in the hinterland of Gambia, where he was enslaved when he was still a young man. Brought to the coast, he was sold into slavery to a German medical doctor and slave merchant, named Daniel Botefeur, who had been living in Bunce Island, Sierra Leone, for several years. In 1815, master and slave moved to Cuba, where they joined a community composed of men and women of various status and nationalities. Navigating the intersections of micro-history and macro-history, Zeuske demonstrates how, despite their different stories, these two men can be defined as cosmopolitans of the "hidden" Atlantic world.

The paper "From Beyond the Kwango: Tracing the Origins of Slaves Leaving Angola, 1811-1848" by Daniel B. Domingues da Silva and Badi Bukas-Yakabul studies the origins of the liberated Africans from Cuba and Sierra Leone during the nineteenth century. The paper examines the records made available on the African Origins Portal (http://www.africanorigins.org) in order to estimate the number of enslaved Africans from the region of Angola along with their ethno-linguistic distribution. Challenging previous studies about the origins of slaves in that geographical area, the authors show that only approximately 21 percent of the captives embarked in Angola during the nineteenth century came from the zone beyond the Kwango River. In addition to contributing to identify the origins of enslaved Africans imported to the Americas, the article underscores how 
collaborative work and the study of African languages are crucial elements for the development of research on the Atlantic slave trade.

From West Africa and West Central Africa, the next articles move the focus to Braizl. Most works examining the arrival of slave ships in Brazilian shores during the era of the Atlantic slave trade have focused on the ports of Rio de Janeiro and Salvador. Historians Marcus J. M. de Carvalho and Aline Emanuelle De Biase Albuquerque explore the history of the slave trade to Brazil before its legal prohibition in 1831. The authors examine the medical and hygiene procedures applied to slave ships that arrived from Africa at the port of Recife in Pernambuco. The paper explains the role of the various social actors involved in the disembarkation process, and the horrible transportation conditions to which Africans were submitted during the Middle Passage, by contributing to the understanding of the Atlantic slave trade in the third largest Brazilian slave port.

Mariana Dantas explores the history of black women and women of color in colonial Minas Gerais, in Brazil. Examining notarial records such as post-mortem inventories, testaments, and deeds executed in Sabará, county of Rio das Contas, during the second half of the eighteenth century, she shows how women of color were able to achieve some social mobility. The paper discusses the processes through which these women challenged the existing social and racial boundaries. She shows how despite in difficult conditions these women were able to assure the transmission of property, including slaves, to their male and female children. Dantas argues that their actions contributed to create a social environment in which populations of color could occasionally appropriate notions of honor and social prestige in order to negotiate (and perhaps mitigage) the impact of African ancestry in their own social position and that of their descendants.

Mariana Muaze's paper discusses the relations between masters and enslaved women who worked as domestic servants in the big house of one of the largest and oldest coffee estates in the region, the Pau Grande plantation, located in Paty do Alferes, in Rio de Janeiro's Paraiba Valley. Although enslaved women expected that the reciprocal affection ties with their masters would help them to obtain manumission papers, Muaze shows that gaining freedom always remained an uncertain achievement. Aware of their power, masters constantly played with these expectations in order to exert control on their slaves. Muaze's work contributes to shed light on how domestic slave labor was pervasive in Brazil and how its legacies still persist today.

In the final paper of this number, Ynaê Lopes dos Santos compares urban slavery in Havana and Rio de Janeiro between 1816 and 1820. This period was marked by the fall of Napoleon Bonaparte and the Congress of Vienna, along with the rise of the British abolitionist movement, events that seemed to put in danger the continuation of slavery in the near future. Relying on a number of reports produced by the administrative authorities of Havana and Rio de Janeiro, Santos shows how these officials utilized their detailed knowledge of the urban tissue in order to control the slave populations which were rapidly growing in the two cities. Focusing on a period, when fear of rebellion haunted slave masters even in the cities, Santos's article contributes to the comparative study of urban slavery in the Americas from an Afro-Atlantic perspective.

Assembling works focusing on the history of slavery and the Atlantic slave trade in the South Atlantic system, the various articles of this number 
conceive slavery and the slave trade as resulting from interconnected relations, which were also indebted to particular social, economic, and cultural dynamics that evolved in African societies.

Through the study of the multiple dimensions of the Afro-Atlantic connections and by combining a variety of approaches combining microhistory and macro-history, as well as demography and urban history, the various articles illuminate how the broader mechanisms of the Atlantic slave affected the daily lives of enslaved men and women in Brazil and Cuba. We hope that such works encourage the development of new comparative research on other slave societies in the Americas. 